\title{
MARKED INCREASES IN LARGE ENKEPHALIN-CONTAINING POLYPEPTIDES IN THE RAT ADRENAL GLAND FOLLOWING DENERVATION $^{1}$
}

\author{
RANDOLPH V. LEWIS, ${ }^{2}$ ALVIN S. STERN,${ }^{3}$ DANIEL L. KILPATRICK, LOUISE D. GERBER, \\ JEAN ROSSIER, ${ }^{4}$ STANLEY STEIN, AND SIDNEY UDENFRIEND
}

Roche Institute of Molecular Biology, Nutley, New Jersey 07110

\begin{abstract}
When rat adrenal glands are denervated, large increases in the amounts of enkephalin and enkephalincontaining polypeptides appear. In the normal gland, only trace amounts occur. One of the larger polypeptides (approximately 22,000 daltons) increases rapidly and by $48 \mathrm{hr}$ following denervation, attains 20 times its original level. At this time, the levels of free enkephalins are essentially unchanged. By $96 \mathrm{hr}$, the 22,000-dalton polypeptide begins to decrease as free enkephalins and intermediate-sized enkephalincontaining polypeptides increase. This series of events is consistent with a precursor $(22,000$-dalton polypeptide)/product (enkephalin) relationship.
\end{abstract}

In the original studies describing Met-enkephalin immunoreactive material in adrenal medullary cells, Schultzberg et al. (1978) noted that the rat differed from other species. Only after sectioning the splanchnic nerve did a substantial proportion of the rat adrenal medullary cells react positively for Met-enkephalin. Subsequently, we found that the bovine adrenal medulla contains not only large amounts of enkephalins but also enkephalincontaining polypeptides, presumably precursors and intermediates of the pentapeptides (Lewis et al., 1979, 1980a). These polypeptides range in size from hexapeptides to polypeptides $>50$ kilodaltons $(\mathrm{kDal})$ and, except for the enkephalin sequence, are not homologous with the known opioid-containing peptides in the pituitary gland, i.e., $\beta$-endorphin, $\beta$-lipotropin, and pro-opiocortin (Lewis et al., 1979; 1980a). We have purified and characterized many polypeptides containing the enkephalin sequence. These are of varying sizes: $22,14,8,5$, and 4 $\mathrm{kDal}$ in addition to hexa- and heptapeptides (Lewis et al., 1980a, b; Kimura et al., 1980; Stern et al., 1979, 1980). Now we have investigated the effects of denervation on rat adrenal gland and find, as previously reported (Schultzberg et al., 1978), that the untreated glands contain very small amounts of enkephalin. The untreated glands also contain larger enkephalin-containing polypeptides (approximately $22 \mathrm{kDal}$ ). Following denerva-

\footnotetext{
${ }^{1}$ We wish to thank Ms. D. V. Torres for the preparation of this manuscript.

${ }^{2}$ Present address: University of Wyoming, Department of Biochemistry, Laramie WY 82071.

${ }^{3}$ To whom all correspondence should be addressed.

${ }^{4}$ Present address: Physiologie Nerveuse, Centre National de la Recherche Scientifique 91190, Gif-sur-Yvette, France.
}

tion, enkephalin levels remain essentially unchanged for over 2 days, whereas the $22-\mathrm{kDal}$ polypeptide increases rapidly and attains values 20 times the levels of the controls. Increases in free enkephalin and the smaller enkephalin-containing polypeptides appear much later.

\section{Materials and Methods}

Rats (150 to $200 \mathrm{gm}$ ) with unilaterally denervated adrenal glands were obtained from Taconic Farms (Germantown, NY). They were killed by decapitation and the adrenal glands were removed and frozen in liquid nitrogen within 2 min after death. The denervated (left side) and control glands (right side) were pooled and homogenized as described (Lewis et al., 1979). After centrifugation, the supernatant solution was fractionated on Sephadex G-75 $(1.25 \times 60 \mathrm{~cm})$ which had been equilibrated in the extraction buffer. Portions from each fraction were lyophilized, redissolved in $400 \mu \mathrm{l}$ of $50 \mathrm{~mm}$ Tris$\mathrm{HCl}(\mathrm{pH} 8.5)$, and digested with $1 \mu \mathrm{g}$ of L-1-tosylamido-2-phenylethyl chloromethyl ketone (TPCK)-treated trypsin for $16 \mathrm{hr}$ at $37^{\circ} \mathrm{C}$. The tryptic digests were treated with $0.1 \mu \mathrm{g}$ of carboxypeptidase $\mathrm{B}$ for $2 \mathrm{hr}$ at $37^{\circ} \mathrm{C}$ and then for $20 \mathrm{~min}$ at $90^{\circ} \mathrm{C}$ to inactivate the enzyme. The samples were then assayed for opioid activity by a radioreceptor binding assay using neuroblastoma-glioma hybrid cells with $\left[{ }^{3} \mathrm{H}\right]$ tyrosine-labeled Leu-enkephalin as the competing ligand (Gerber et al., 1978).

\section{Results and Discussion}

Small amounts of enkephalins and enkephalin-containing polypeptides were detected in the untreated rat adrenal gland (Fig. 1). However, a dramatic effect was produced upon denervation of the gland. Twenty-four hours after denervation (Fig. $2 A$ ), a large increase in the 


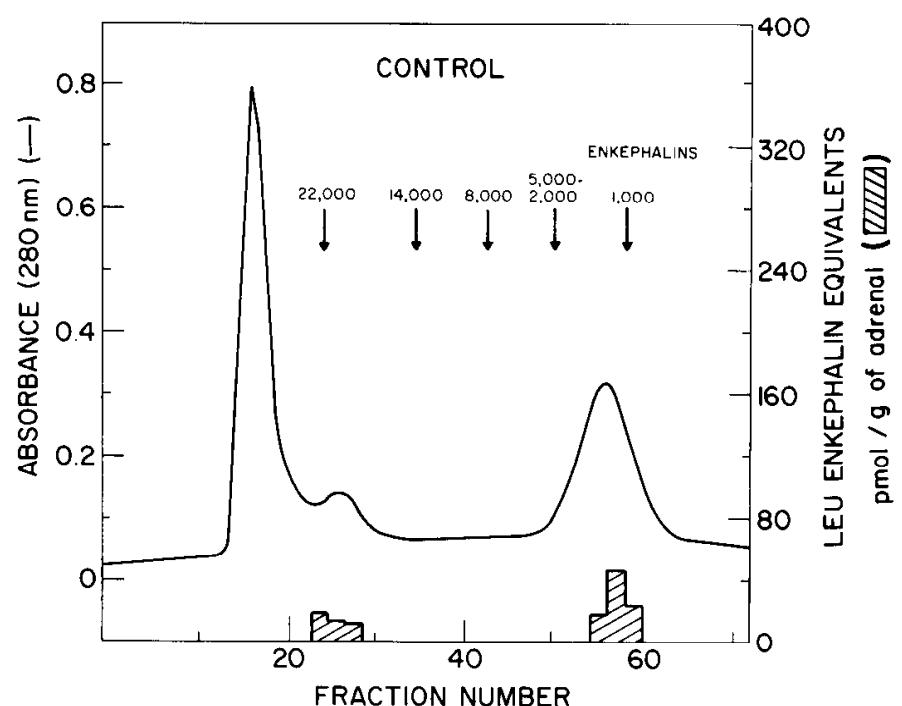

Figure 1. Sephadex G-75 chromatography of extracts of control rat adrenal glands. Control glands $(n=14)$ were pooled. The amounts are presented as total enkephalin equivalents and are not corrected for losses during extraction and chromatography. The elution positions of the characterized enkephalincontaining polypeptides and enkephalins are presented as reference standards. The data presented in Figures 1 and 2 are representative of one of the four experiments performed.

22-kDal enkephalin-containing polypeptide was observed; free enkephalins were essentially unchanged. At this time, the $22-\mathrm{kDal}$ polypeptide had increased more than 12 -fold to 560 pmol per gland. A small amount ( 40 pmol) of the 14-kDal polypeptide also appeared. After 48 hr (Fig. $2 B$ ), the 22-kDal polypeptide had increased to $970 \mathrm{pmol}$ and the $14-\mathrm{kDal}$ polypeptide had increased to more than 100 pmol; enkephalin levels were still unchanged.

The pattern of enkephalin-containing polypeptides observed $96 \mathrm{hr}$ after denervation (Fig. 2C) resembled qualitatively that seen in extracts of bovine adrenal chromaffin granules (Lewis et al., 1979). In contrast to what was observed 24 and $48 \mathrm{hr}$ following denervation, enkephalins had now increased 4-fold to $330 \mathrm{pmol}$. Also, appearing for the first time were the 8-kDal enkephalin-containing polypeptide $(180 \mathrm{pmol})$ and the group of $3-$ to $5-\mathrm{kDal}$ peptides $(80 \mathrm{pmol})$. The $14-\mathrm{kDal}$ polypeptide had increased to $360 \mathrm{pmol}$. In contrast, the $22-\mathrm{kDal}$ polypeptide had decreased to 300 pmol.

Table I summarizes the total enkephalin content of the rat adrenal gland at various times following denervation and compares the levels of enkephalin-containing polypeptides to those of free enkephalin. The increase in the largest enkephalin-containing polypeptide appeared to be linear for up to $48 \mathrm{hr}$. After $48 \mathrm{hr}$, there was only a slight increase in the total enkephalin content, but the distribution among the various polypeptides was greatly altered (compare Fig. 2, $B$ and $C$ ). It should be noted that even at the 96-hr time point, the total enkephalin content (free and in polypeptide form) was much less than is present in normal bovine adrenal glands.

Identification of the enkephalin-containing polypeptides in the denervated rat adrenal gland with those in beef adrenal chromaffin granules has yet to be estab- lished. However, the molecular weights estimated from gel permeation chromatography are similar, suggesting close homology of the polypeptides isolated from the two sources. A most interesting point is that the time course of appearance of the large enkephalin-containing polypeptides and of free enkephalins in the denervated rat adrenal is that expected for a precursor/product relationship (Rossier et al., 1980), i.e., increases first in the enkephalin-containing polypeptides and only later in the amount of free enkephalin. Thus, denervation appears to provide a powerful stimulus for enkephalin synthesis. Less likely is the possibility that the increase in enkephalin-containing polypeptides is due to a decreased rate of

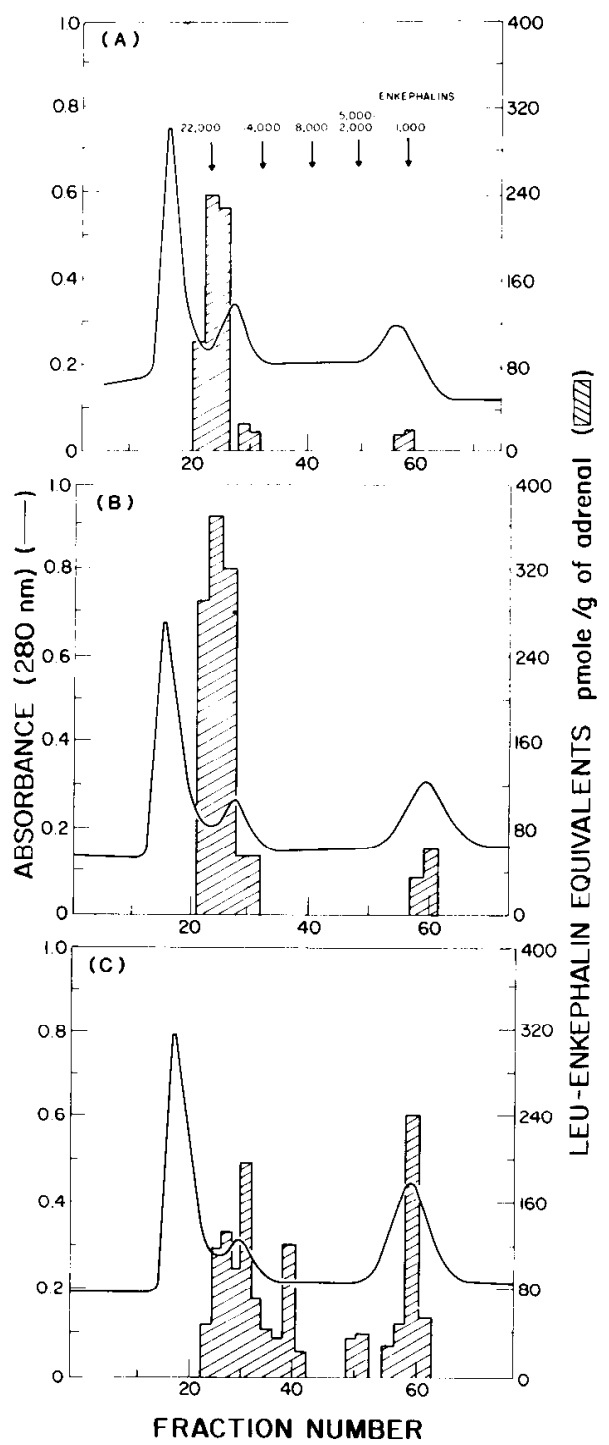

Figure 2. Sephadex G-75 chromatography of extracts of denervated rat adrenals. Rats were killed 24,48 , and $96 \mathrm{hr}$ following unilateral denervation (left side). All extraction and chromatographic conditions were the same as described in Figure 1 for the control adrenal extracts. $A, 24 \mathrm{hr}(n=14) ; B$, $48 \mathrm{hr}(n=14) ; C, 96 \mathrm{hr}(n=20)$ following denervation. 'There was considerable variability among the experiments. However, in all experiments, the large enkephalin-containing polypeptides were increased manyfold by 48 to $72 \mathrm{hr}$ after denervation, whereas "free enkephalins" were essentially unchanged. 
TABLE I

Levels of adrenal enkephalins and enkephalin-containing polypeptides at various times following denervation

\begin{tabular}{cccc}
\hline $\begin{array}{c}\text { Time after } \\
\text { Denervation }\end{array}$ & $\begin{array}{c}\text { Enkephalin- } \\
\text { containing } \\
\text { Polypeptides }^{t}\end{array}$ & Enkephalins $^{b}$ & Total \\
\hline$h r$ & 45 & pmol/gm & 133 \\
Control & 600 & 88 & 668 \\
24 & 1070 & 68 & 1176 \\
48 & 920 & 106 & 1250 \\
96 & 330 & \\
\hline
\end{tabular}

${ }^{a}$ The values are calculated from Figures 1 and 2 and represent the total enkephalin content of all polypeptides above $3 \mathrm{kUal}$ following digestion with trypsin and carboxypeptidase B; they are presented as picomoles of Leu-enkephalin equivalents per gram of adrenal.

${ }^{b}$ Values are maximum amounts since these fractions also contain the hexa- and heptapeptides (Stern et al., 1980) which may represent as much as $25 \%$ of the total "free" enkephalin activity.

their degradation. It is conceivable that denervation may cause massive splanchnic stimulation of the adrenal medulla at the time of surgery. This, in turn, may lead to increased biosynthesis of enkephalin precursors by a process analogous to the trans-synaptic induction of tyrosine hydroxylase (Thoenen et al., 1969a, b). Alternatively, in the absence of release, there may be an accumulation of enkephalin-containing polypeptides in the denervated glands. The delay in appearance of free enkephalins for over $48 \mathrm{hr}$ may reflect the time required for maturation of adrenal chromaffin granules. The largest precursor (perhaps $>50 \mathrm{kDal}$ (Lewis et al., 1980c)) may be taken up by the newly formed granules and undergo proteolytic processing during the maturation process.

It should be noted that at all times following denervation, free enkephalins represented only a minor component of the total enkephalin content of the adrenal. Therefore, one cannot rule out the possibility that the purpose of this metabolic pathway is to produce an adrenal opioid hormone which is not free enkephalin but one of the larger enkephalin-containing polypeptides.

The question remains as to why the untreated rat adrenal gland contains so much less of the enkephalins and precursors than the bovine gland. This may be related to differences in metabolism and turnover or to the physiological states of the animals at the time of death. Whatever the reasons for the large quantitative differences between these two species, the present findings indicate that rat and bovine adrenal glands produce enkephalins via a pathway involving the same types of precursor polypeptide intermediates.

\section{References}

Gerber, L. D., S. Stein, M. Rubinstein, J. Wideman, and S. Udenfriend (1978) Binding assay for opioid peptides with neuroblastoma $\times$ glioma hybrid cells: Specificity of the receptor site. Brain Res. 151: 117-125.

Kimura, S., R. V. Lewis, A. S. Stern, J. Rossier, S. Stein, and S. Udenfriend (1980) Probable precursors of [Leu]enkephalin and [Met]enkephalin in adrenal medulla: Peptides of 3-5 kilodaltons. Proc. Natl. Acad. Sci. U. S. A. 77: 1681-1685.

Lewis, R. V., A. S. Stern, J. Rossier, S. Stein, and S. Udenfriend (1979) Putative enkephalin precursors in bovine adrenal medulla. Biochem. Biophys. Res. Commun. 89: 822-829.

Lewis, R. V., A. S. Stern, S. Kimura, J. Rossier, L. Brink, L. D. Gerber, S. Stein, and S. Udenfriend (1980a) Opioid peptides and precursors in the adrenal medulla. In Neural Peptides and Neural Communication, E. Costa and M. Trabucchi, eds., pp. 167-179, Raven Press, New York.

Lewis, R. V., A. S. Stern, S. Kimura, S. Stein, and S. Udenfriend (1980b) Enkephalin biosynthetic pathway: Proteins of 8000 and 14,000 daltons in bovine adrenal medulla. Proc. Natl. Acad. Sci. U. S. A. 77: 5018-5020.

Lewis, R. V., A. S. Stern, S. Kimura, J. Rossier, S. Stein, and S. Udenfriend (1980c) An about 50,000 dalton protein in adrenal medulla: A common precursor of [Met]- and [Leu]enkephalin. Science 208: 1459-1461.

Rossier, J., J. Trifaro, R. V. Lewis, R. W. H. Lee, A. S. Stern, S. Kimura, S. Stein, and S. Udenfriend (1980) Studies with ${ }^{35} \mathrm{~S}$-methionine indicate that the 22,000 dalton Met-enkephalin containing protein in chromaffin cells is a precursor of Met-enkephalin. Proc. Natl. Acad. Sci. U. S. A. 77: in press.

Schultzberg, M., J. M. Lundberg, T. Hökfelt, J. Brandt, R. P. Elde, and M. Goldstein (1978) Enkephalin-like immunoreactivity in gland cells and nerve terminals of the adrenal medulla. Neuroscience 3: 1169-1186.

Stern, A. S., R. V. Lewis, S. Kimura, J. Rossier, L. D. Gerber, L. Brink, S. Stein, and S. Udenfriend (1979) Isolation of the opioid heptapeptide Met-enkephalin $\left(\mathrm{Arg}^{6}-\mathrm{Phe}^{7}\right)$ from bovine adrenal medullary granules and striatum. Proc. Natl. Acad. Sci. U. S. A. 76: $6680-6683$.

Stern, A. S., R. V. Lewis, S. Kimura, J. Rossier, S. Stein, and S. Udenfriend (1980) Opioid hexapeptides and heptapeptides in adrenal medulla and brain: Possible implications on the biosynthesis of enkephalins. Arch. Biochem. Biophys. 204: in press.

Thoenen, H., R. A. Mueller, and J. Axelrod (1969a) Increased tyrosine hydroxylase activity after drug-induced alteration of sympathetic transmission. Nature 221: 1264-1265.

Thoenen, H., R. A. Mueller, and J. Axelrod (1969b) Transsynaptic induction of adrenal tyrosine hydroxylase. J. Pharmacol. Exp. Ther. 169: 249-254. 